\title{
AN INSTRUCTIONAL MODEL FOR ENHANCING EFL LEARNERS' SPEAKING PROFICIENCY
}

\author{
Syarifudin \\ UIN Mataram, syarif@uinmataram.ac.id
}

\begin{abstract}
Due to the central role of speaking skill and its escalating demands of instruction in various levels of education in Indonesia, a myriad of teaching approaches and strategies have been applied to equip learners with the competences enabling the development of this skill. As a widespread approach to English language teaching (ELT), which gains its popularity within the context of EFL, Communicative Language Teaching (CLT) is geared towards learners' communicative competence comprising of grammatical competence, discourse competence, sociolinguistic competence, and strategic competence as the underlying abilities of speaking proficiency. The development of these competences can be better facilitated when learning takes its place both in and outside classrooms as the latter provides potential promises for learners' speaking proficiency development. For this reason, this paper presents learners' challenges for learning speaking, the model activities in and outside classrooms, the importance of speaking instruction and the components of communicative competence and speaking proficiency.
\end{abstract}

Keywords: CLT, communicative competence, speaking proficiency.

\section{Introduction}

As a tool of oral communication, apparently speaking English has always fascinated people. A large number of English language learners are highly motivated to master this skill. Speaking is one of their main purposes of learning English because being able to speak in English brings personal satisfaction, and it is assumed that it can facilitate the attainment of one's professional goals. In addition, speaking is generally used as the initial measurement of one's English language acquisition. "Can you 
speak English?", for example, is always uttered when one wants to know the extent to which another has mastered the learnt language. Similarly, Nunan (1991:39) states that to most people, mastering speaking skill is the single most important aspect of learning a second language or foreign language, and success is measured in terms of the ability to carry out a conversation in the language. It means that the ability to speak English proficiency has always become the most imperative purpose for the learners in learning English as a foreign language in Indonesia. One of the criteria for a person who is able to speak English proficiency is measured by the way he or she articulates English sounds despite being able to describe different topics in English. Speaking seems intuitively the most important of the four skills (listening, speaking, reading and writing). People who know a language are referred to as 'speakers' of that language, as if speaking included all other kinds of knowing; and many if not most foreign learners are primarily interested in learning to speak (Ur, 1996:120).

As a productive language skill speaking would probably be the most difficult to learn because it needs drill through oral communicative way. Learners must be encouraged to engage in English Speaking activities, both inside and outside classroom. It should be created the sufficiency environment in order to facilitate English learners in improving their speaking skill. Richard (1990) states that oral skills have hardly been neglected in EFL/ESL course (witness the huge number of conversation and other speaking course books in the market) though how the best to approach the teaching of oral skills has long been the focus of methodological debate. It means we do not debate about the approach in teaching speaking skill, but teachers and textbooks make use of a variety of approaches and focusing on specific features of oral interaction to give opportunities for the learners to practice the language in communicatively.

The purpose of teaching and learning English based on School-Based Curriculum (2006) is to enable learners to master and use English communicatively. The Regulation of the Ministry of National Education No. 23/2006 specifies the standard competencies of speaking English for senior high school learners, that the learners express oral meaning in formal and informal interpersonal and 87 
transactional discourse, in the forms of recount, narrative, procedure, descriptive, news item, report, analytical exposition, hortatory exposition, spoof, explanation, discussion, and review, in everyday life contexts (Permendiknas, 2006:12).

However, it is very difficult for the EFL learners to reach all of the standard competencies of speaking English, which are stated in the curriculum because of some problems such as learners' motivation, types of speaking activities, opportunities to practice speaking, and also learners' linguistic and personality, teaching and learning strategies, course materials, environment factors. Such drawbacks make the learners reluctant to engage in English speaking activities either inside or outside classroom.

\section{The EFL Learners' Problems in Speaking English}

The EFL learners face many problems in engaging in speaking activities either inside or outside the classroom, such as Snell (2010) states that a common problem for EFL learners is dealing with a passive class, where learners are unresponsive and avoid interaction with the teacher and other learners. This is especially true when a teacher seeks interaction in a teacher-class dialog, such as asking questions to the class as a whole, expecting at least one learner to respond. Regarding the learners' problem in speaking English, Padmadewi (1998) in her research found that learners attending a speaking class often felt anxious due to pressure from the speaking tasks which require them to present individually and spontaneously within limited time. Moreover, based on her research Tutyandari (2005) explained that learners keep silent because they lack self-confidence, lack prior knowledge about topics, and because of poor teacher-learner relationship.

Regarding the learners' problems in English speaking, Defrioka (2009) in her research depicts that common problem for EFL teacher is dealing with a passive class, where learners are unresponsive and avoid interaction with the teacher and other learners. This is especially true when a teacher seeks interaction in teacher-class dialog, such as asking question to the class as the whole and expecting at least one learner to respond. Ur (1996:121) states that some problems with speaking activities are: learners are often inhabited about trying to say things in a foreign language in the classroom, they have no motive to express themselves beyond the 
guilty that they should be speaking, low or uneven participation, and the learners may tend to use mother tongue. In line with that Padmadewi (1998) in her research found that learners attending a speaking class often felt anxious due to pressure from the speaking tasks which require them to present individually and spontaneously within limited time. Moreover, based on her research Tutyandari (2005) explained that learners keep silent because they lack self-confidence, lack prior knowledge about topics, and because of poor teacher-learner relationship.

Learners' problems in speaking always occur in every speaking activities, such as low motivation, reluctant and uneven participation to engage in English speaking activities. Brown (2007) commended that one of the more complicated problem of foreign language learning and teaching has been to define and apply the construct of motivation in participating to the interaction. It is very necessary to construct learners' motivation in language learning, both intrinsic and extrinsic motivation.

In self-determination theory Deci and Ryan (1985) quoted in Dornyei (2002) explained that intrinsic motivation concerns behaviour performed for its own sake in order to experience pleasure and satisfaction such as the joy of doing a particular activity or satisfying one's curiosity. While extrinsic motivation involves performing a behaviour as a means to an end that is to receive some extrinsic reward or to avoid punishment.

In order to motivate the learners engage in speaking activities or interaction outside the classroom, school parties or teachers must create school environment which enable the learners interact to use English in real communication and learners' opportunities for exposure to the target language and for language practice. Environmental influences can engender learners' motivation as Wentzel (1999) quoted in Dornyei (2002) in social motivation theory state that a great deal of human motivation stems from the sociocultural context rather tha from the individual. In this matter, communicative language activities environment stimulate learners' foreing language interaction and learners can benefit from participating in naturally occurring conversations. Learners are encouraged to have higher motivation in learning foreign language, particularly to involve themselves in speaking activities in order to be able to perform oral communication in real interaction. 
On that account, it requires endeavor through a systematic and programmatic teaching and learning process to the speaking skill in order to more facilitate the learners to communicate and interact with the teacher and other learners. Teachers have an important role in fostering learners' ability to speak English well, encouraging them to speak English more often either inside or outside classroom activities. Regarding to teaching speaking, Syamsurizal (2008) in his research stated that the teaching of speaking in a target language should enable the learners to use the language orally for many purposes just as they do in their native language. While Padmadewi (1998) advised speaking teachers activate the learners' prior knowledge by asking questions related to topics under discussion. She also mentioned that learners' self- confidence can be enhanced and their anxiety reduced by giving them tasks in small groups.

\section{Engaging EFL Learners in Speaking Activities Inside and Outside the Classroom}

As the model of EFL Learners' speaking activities inside and outside the classroom, the writer interests to depict a little bit of the situation in the Islamic Boarding School context. Based on investigation at Islamic Boaridng School in Lombok, teaching of English speaking for junior and senior high school learners in Islamic Boarding School context is different with senior high school in general, because it gives opportunities for the learners to engage in English speaking activities in particular atmosphere and time either inside or outside classroom. English speaking activities inside classroom setting involves interactions between learners and teacher and between learners and learners. The learners are expected to be able to express themselves in English language for both transactional and interactional purposes.

Gebhard (2000:169) states both types of interaction frequently exist is speaking, inside or outside the classroom, and the teacher ought to ensure that his or her learners have the competence to apply them. While English speaking activities outside classroom, the learners engage in particular scheduled time such as, English speaking week, morning English conversation, afternoon English speaking, English debate, public speaking, 
outdoor English meeting which enable the learners' opportunities to engage themselves to practice speaking English. In relation to opportunities, Rivers (1968: 160) states that the teacher will need to give the learners many opportunities to practice the speaking skill; he will to use imagination in devising situations which provoke the learner to the use of the language in the expression of his own meaning, within the limits of what he has been learning. The importance and the need for speaking English in the teaching of English in Islamic Boarding School have been explicitly stated in several official rules released by the institution, especially those related to some activities that are carried out of outside the classroom to practice speaking English. Futhermore, Mukminatien (1999) suggested teachers provide their learners with more sufficient input for acquisition in the classroom and encourage them to use English in or outside the classroom. Because the ability to speak in the target language is essential, it is important to give learners appropriate tasks that ensure and aid them to master the speaking skill. The teacher is obliged to provide appropriate ways, strategies, or techniques that help learners to speak in the language.

\section{The Importance of Teaching Speaking}

Teaching of speaking to the EFL learners needs, is one of the most important in learning a foreign language especially English. In a very general usage, speaking a language clearly entails many different purposes which are important to be remembered that in teaching speaking deems entirely upon the learner's ultimate purpose in learning to speak English. Folse (2009:4) states that teachers need to know why learners want to speak English, whether it is for study, business, job, and to be able to communicate at all activities. This coincided with Richards and Renandya (2002:201) who argued that speaking is used for many different purposes, and each purpose involves different skills. When speakers use casual conversation, for example, the purposes may be to make social contact with people, to establish rapport, or to engage in the harmless chitchat that occupies much of the time they spend with friends. In some situations, speakers use speaking to give instructions, to describe things, to entertain people, other speaking purposes. Richards and Renandya (2002:201) further argued that each of these different purposes for speaking implies knowledge of the 
rules that account for how spoken language reflects the context or situation in which speech occurs, the participants involved and their specific roles and relationships, and the kind of activity the speakers are involved in.

The main purpose of teaching speaking to EFL learners is to improve learners' spoken communication skill, so they are able to express themselves using the target language appropriately based on the context which they need. In an attempt to improve the learners' speaking competence in EFL, the demand to teach speaking English is increasing more and more in all levels of education in Indonesia. Many kinds of approaches and methods are applied in teaching and learning process of speaking in order to enable the learners to perform the microskills and macroskills of communication. The widely accepted instructional method in teaching speaking is communicative language teaching (CTL) which emphasizes that the goal of language learning is to increase learners' communicative competence. Harmer (2007:69) states that a major stand of CLT centers around the essential belief that if learners are involved in meaning focused communicative tasks, then language learning will take care of itself, and that plentiful exposure to language in use and plenty of opportunities to use it are vitally important for a learners' development of knowledge and skill.

\section{Communicative Competence and Speaking Proficiency}

To improve speaking proficiency depends on aspects of communicative competence which are abilities underlying of speaking proficiency as Richards and Renandya (2002: 201) introduce the useful model developed by Canale and Swain to account for the components of speaking ability. This model describes speaking proficiency as depending on grammatical competence, discourse competence, sosiolinguistic competence, and strategic competence, each of which needs to be addressed in a speaking course and teaching. Savignon (1983:22) defined communicative competence as the ability to function in a truly communicative setting in a dynamic exchange in which linguistic competence must adapt itself to the total informational input, both linguistic and paralinguistic, of one or more interlocutors. Furthermore, Brown (2000:246) referred to communicative competence as that aspect of 
our competence that enables us to convey and interpret messages and to negotiate meanings interpersonally within specific contexts.

Four different components or subcategories of communicative competence proposed by Canale and Swain (1980) quoted by Shumin (2002) include grammatical competence, discourse competence, sociolinguitic competence, and strategic competence, reflect the use of the linguistic system and the functional aspects of communication respectively. The first two components reflect the use of the linguistic system itself and the last two define the functional aspects of communication. Those four components of communicative competence are going to be explained more detail in the further working through ideas.

Grammatical competence is mastery of the linguistic code, the ability to recognize the lexical, morphological, syntactic, and phonological features of a language and to manipulate these to form words and sentences (Savignon, 1983:37). In line with that Huda (1999:32) explains that grammatical competence involves the mastery of language codes both verbal and nonverbal, such as vocabulary, derivation, sentence formation, pronunciation, spelling, and semantics. In addition, grammatical competence is an umbrella concept that includes increasing expertise in grammar (morphology, syntax), vocabulary, and mechanics. With regards to speaking, the term mechanics refers to basic sounds of letters and syllables, pronunciation of words, intonation, and stress (Shumin (2002:207).

Discourse competence is the connection of a series of sentences or utterances to form a meaningful whole (Savignon, 1993:38). This coincided with (Brows, 2000:247) that discourse competence is the ability to connect sentences in stretches of discourse and to form a meaningful whole out of series of utterance Furthermore, Kamiya, (2007) explains that discourse competence is the mastery of rules concerning cohesion and coherence of various kinds of discourse in SL/FL (e.g. use of appropriate pronouns, synonyms, conjunctions, etc.).

Sociolinguistic competence is the knowledge of the sociocultural rules of language and of discourse. This type of competence requires an understanding of the social context in which language is used (Brows, 2000:247). Huda (1999:33) explains that sociolinguistic competence relates to the extent an 93 
utterance is expressed and understood correctly in different sociolinguistic contexts, which in turn depend on certain factors such as speaker- listener status, the objective of the interaction, and the rules and norms of the interaction. In addition, Shumin (2002:207) stated that understanding the sociolinguistic side of language helps learners know what comments are appropriate, how to ask questions during interaction, and how to respond nonverbally according to the adaptability in order to be able to encode and decode the discourse around them correctly.

Strategic competence, which is the way learners manipulate language in order to meet communicative goals (Brown, 1994:228), is perhaps the most important of all the communicative competence elements. Kamiya (2007) described strategic competence is the mastery of verbal and nonverbal communication strategies in SL/FL used when attempting to compensate for deficiencies in the grammatical and sociolinguistic competence or to enhance the effectiveness of communication (e.g. paraphrasing, how to address others when uncertain of their relative social status, slow speech for rhetorical effect, etc.).

Description of four components of communicative competences are very clear with intention is to discover the kinds of knowledge and skills that EFL learners need abilities underlying to develop their English speaking proficiency through understanding and applying those communicative competence. Speaking proficiency can be gained by the EFL learners through practice speaking both inside and outside the classroom or other places where enable to engage in using spoken English in real life.

\section{Conclusion}

In this writing the writer has tried to depict an attempt to enhance of EFL learners' speaking proficiency through understanding of learners' speaking problems, engaging them in speaking activities, and teaching of speaking with appropriate methods and activities. Teaching of speaking to the learners is the most important in learning a foreign language especially English. One of the widely accepted instructional methods in teaching speaking is CLT, in which this method emphasizes that the goal of language learning is communicative competence. Communicative competence includes grammatical competence, discourse competence, sociolinguistic 
competence, and strategic competence, as abilities underlying speaking proficiency. Description of four components of communicative competences are very clear with intention is to discover the kinds of knowledge and skills that EFL learners need abilities underlying to develop their English speaking proficiency through understanding and applying those communicative competence. Speaking proficiency can be gained by the EFL learners through practice speaking both inside and outside the classroom activities or other places where enable to engage in using spoken English in real life.

In teaching speaking in order more communicative, teacher must be able to use many kinds of speaking activities, such as role play and simulation, information gap, group solving problem, and other speaking activities. Speaking activities can be carried out both inside and outside the classroom depends on speaking goals. Those activities enable the learners to engage in interaction in real communication to improve speaking proficiency.

\section{References}

Brown, H. D. (2007). Teaching by principle: An interactive approach to language pedagogy. San Fransisco: Longman.

Brown, H. D. (2000). Principles of language learning and teaching. San Fransisco: Longman.

Andri, D. (2009). Improving learners' interaction in speaking class through information gap activities. Paper presented in the $56^{\text {th }}$ TEFLIN International Conference, Batu-Malang Indonesia, 8 - 10 December 2009.

Zoltan, D. (2002). Motivational strategies in the language classroom. Cambridge: Cambridge University Press.

Mary, F., \& Christopher, B. (1985). The functional-notional approach: From theory to practice. New York: Oxford University Press.

Keith, F S. (2007). The art of teaching speaking: $A$ research and pedagogy for the ESL/EFL classroom. Ann Arbor: The University of Michigan Press.

Omaggio, H. A. (1993). Teaching language in context. Boston: Heinle \& Heinle Publishers.

Jeremy, H. (1996). The practice of English language teaching. London: Longman. 
Jeremy, H. (2007). The practice of English language teaching. China: Pearson Longman.

Nuril, H. (1999). Language learning and teaching: Issues and trends. Malang: Universitas Negeri Malang Press.

Donna, J. M. (1992). Approaches to research in second language learning. New York: Longman.

Masashito, K. (2007). The role of communicative competence in 12 learning. (Online). Retrieved from http://pdf.finder.com

Tracey, K. L. (2007). Beyond the classroom walls: A study of out of class English use by Adult community College ESL learners. (Thesis). Portland University. (Online). Retrieved from http://pdf.finder.com

Wen-chung, L. (2006). Memorization and Improvisation: A Comparison of Two Strategies in the Oral Acquisition of English as a Second Language. Australia: Australia Catholic University. Dissertation (Online). Retrieved from http://pdf.finder.com

Nur, M. (1999). The problem of developing speaking skills: Limitation of second language acquisition in an EFL classroom. English Language Education, 5(1), 1-10.

David, N. (1996). Language teaching methodology: A textbook for teachers. New York: Prentice Hall.

Padmadewi, N. N. (1998). Learners' anxiety in speaking class and ways of minimizing it. Jurnal Ilmu Pendidikan, 5, 60-67).

Jack, C. R., \& Willy, R. (2002). Methodology in language teaching: An anthology of current practice. Cambridge: Cambridge University Press.

Richards, Jack, C. R., \& Theodore, S. R. (2002). Approaches and methods in language teaching. Cambridge: Cambridge University Press.

Rivers, W. M. (1981). Teaching foreign-language skills. Chicago: The University of Chicago Press.

Savignon, S. J. (1983). Communicative competence: Theory and classroom practice. California: Addison-WESLEY Publishing.

Shumin, K. (2002). Factors to Consider: Developing Adult EFL Learners' Speaking Abilities. In Jack C. Richards and Willy A. Renandya (Eds.), Methodology in Language Teaching: An Anthology of Current Practice (204-211). Cambridge, Cambridge University Press. 
Syarifudin, Instructional Model ...

Supriani, N. (2009). Learners' inbibiting factors in the application of autonomous learning on speaking. Paper 56th TEFLIN International Conference, Batu-Malang Indonesia, 8 - 10 December 2009.

Ur, P. (1996). A Course in language teaching. Practical and theory. Cambridge: Cambridge University Press. 